\title{
Correction to: The Relationship Between Sexual Compulsivity, Emotional and Spiritual Distress of Religious and Non-religious Internet Pornography Users
}

\section{Jason T. Hotchkiss ${ }^{1}$}

Published online: 13 August 2021

() The Author(s), under exclusive licence to Springer Science+Business Media, LLC, part of Springer Nature 2021

\section{Correction to: Journal of Religion and Health (2021) 60:1630-1651 https://doi.org/10.1007/s10943-020-01152-y}

The article "The Relationship Between Sexual Compulsivity, Emotional and Spiritual Distress of Religious and Non-religious Internet Pornography Users", written by Jason T. Hotchkiss, was originally published online on 13 February 2021 with Open Access under a Creative Commons Attribution 4.0 International License.

After publication in volume 60, issue 3, page 1630-1651 the author(s) decided to cancel the Open Access. Therefore, the copyright of the article has been changed on 28 July 2021 to (C) The Author(s), under exclusive licence to Springer Science + Business Media, LLC, part of Springer Nature 2021 with all rights reserved.

The original article has been corrected.

Publisher's Note Springer Nature remains neutral with regard to jurisdictional claims in published maps and institutional affiliations.

The original article can be found online at https://doi.org/10.1007/s10943-020-01152-y.

Jason T. Hotchkiss

Jason.hotchkiss@cornerstone.edu

1 Cornerstone University, 1001 E Beltline Ave NE, Grand Rapids, MI 49525, USA 